\title{
高圧処理を利用した海島型複合短繊維のアルカリ分割
}

\author{
石川県工業試験場 木水 貢, 山本 孝 \\ 福井大学工学部生物応用化学科 久田研次 \\ 福井大学大学院工学研究科 堀 照夫 \\ 日本バイリーン株式会社 宮口典子，山口俊平
}

\section{Alkali Hydrolysis of Islands-in-the-Sea Type Conjugated Short-cut Fibers under High Pressure}

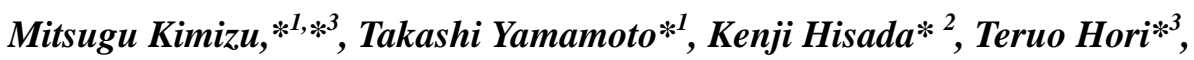 \\ Noriko Miyaguchi* ${ }^{4}$, and Shunpei Yamaguchi* ${ }^{4}$ \\ $*^{l}$ Industrial Research Institute of ISHIKAWA Prefecture, 2-1 Kuratsuki, Kanazawa, Ishikawa \\ 920-0223, Japan \\ $*^{2}$ Department of Applied Chemistry and Biotechnology, Faculty of Engineering, University of Fukui, \\ 3-9-1 Bunkyo, Fukui 910-8507, Japan \\ $*^{3}$ Graduate School of Engineering, University of Fukui, 3-9-1 Bunkyo, Fukui 910-8507, Japan \\ *4 Japan Vilene Co. LTD., 7 Kitatone, Souwa-machi, Ibaraki 306-0213, Japan
}

\begin{abstract}
The conjugated staple fiber of polyester (PET) and polypropylene was divided by the alkaline hydrolysis under the high pressure conditions over $100 \mathrm{MPa}$. The decomposition of the sea element, PET, was accelerated with the temperature and pressure. The addition of the cationic surfactant also enhanced the reaction rate when the concentration was more than $0.5 \mathrm{~g} / \mathrm{L}$. At high surfactant concentration, the acceleration effect was saturated. The high-pressure alkaline hydrolysis gave the fine polypropylene staple fiber by complete elimination of the sea matrix.
\end{abstract}

(Received 21 June, 2004; Accepted 30 August, 2004)

\section{1. 緒 言}

極細繊維を用いた繊維製品は,光の繊維の表面積の大き さ,柔らかさ,なめらかさ, 絨維間に生ずる微細構造等に より柔軟性，ワイピング性，撥水性の特徵を有し，産業資 材分野において各方面で幅広く用いられている.極細纎維 を製造するには幾つかの方法があり，乥の代表的な方法と して 2 成分以上の素材から複合繊維を紡系し，兴の渋維を 分割することで細い纎維を得るものである.2 成分以上の 複合纎維には海島型, 分割・剥離型, 多層型があり，これ らの複合繊維から極細繊維を得る方法には(1)溶阂等によ る一成分の溶解・分離, (2)機械的に录離, (3)化学処理によ る剥離等の方法がある $[1]$. 今回検討した緎維は海島型複

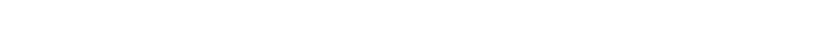
ポリプロピレン) であり, 分割させて極細繊維を得る方法 としては, 海成分であるポリエステルをアルカリによる加 水分解によって除去し，島成分であるポリプロピレンの極 細繊維を得るものである この複合短纎維の溶解処理によ
る分割方法は, 処理中の摫拌 (絡み合い, 分割斑) や処理 液の廃棄において幾つかの問題点を抱えている．艺こで， このアルカリ分割法の効率化を図ることを目的として,超 高圧条件での処理を検討した .100 MPa を超える高圧下で アルカリ処理を行うと,アルカリ剂と高分子の距離や相互 作用などの変化により溶解処理の効率向上か期待できる . 我々はこれまでに , $100 \mathrm{MPa}$ を超える高圧下におけるポリ エステル繊維のアルカリ処理への圧力, 温度等の効果につ いて報告してきた[2,3] .

本研究では, 海島型 (ポリエステル/ポリプロピレン) 複合短繊維のアルカリ分割において, 圧力, 温度および界 面活性剂の添加が分解性へ与える影響について検討した .

\section{2. 実 験}

\section{1 試 料}

試料として, カット長は約 $1.5 \mathrm{~mm}$ の海島型複合短䋐維 (䋐度 3.5dTex，海成分；ポリエチレンテレフタレート， 島成分；ポリプロピレン重量比；52:48，PP 繊維数 61 


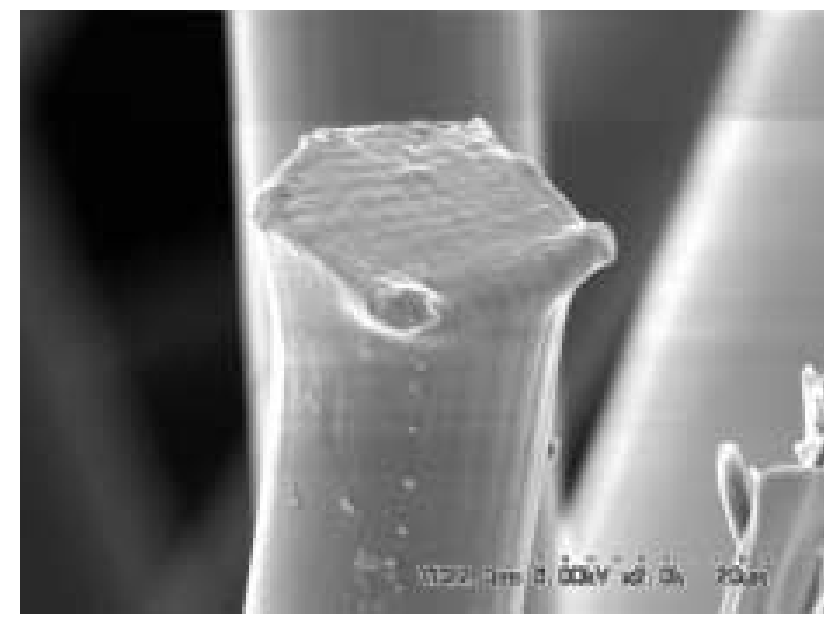

Fig. 1 SEM image of cross section of the conjugated shortcut fiber $(\times 2000)$.

本，PET IV 值 0.6) を使用した . 図 1 には, 今回使用し た海島型複合短繊維の電子顕微鏡写真による断面を示す． 断面に確認される複数の凹凸のうち凸部分が,島成分であ るポリプロピレン部分である .

\section{2 アルカリ溶液の調製}

海島型複合短纎維と濃度 $10.7 \mathrm{wt} \%$ の水酸化ナトリウム 水溶液 (以下 $\mathrm{NaOH}$ 水溶液と称す) の浴比は $1: 10$ と設定 し, 密閉可能なポリ袋中にて反応を行った . また, 緎維表 面のアルカリ処理においては処理斑が生じやすいため，乥 の斑を少なくするためにカチオン系界面活性剤(主成分は ベンジルドデシルジメチルアンモニウムクロライド)を添 加し, 兴の促進効果についても検討した .

\section{3 高圧処理}

一定量 $R_{0}$ の複合短繊維試料と $\mathrm{NaOH}$ 水溶液を入れた袋 を高圧処理装置にて各条件で処理を行った。装置は,ピス トン直圧型の圧力装置で, 約 5 分で所定圧力に到達できる . 高圧処理した試料は，処理後直ちに蒸留水によって洗浄し， 乾燥後に重量 $R_{t}$ を測定した . この後, $95{ }^{\circ} \mathrm{C}$ 以上の 10.7 $\mathrm{wt} \% \mathrm{NaOH}$ 水溶液で 3 時間以上アルカリ処理を行い,繊維

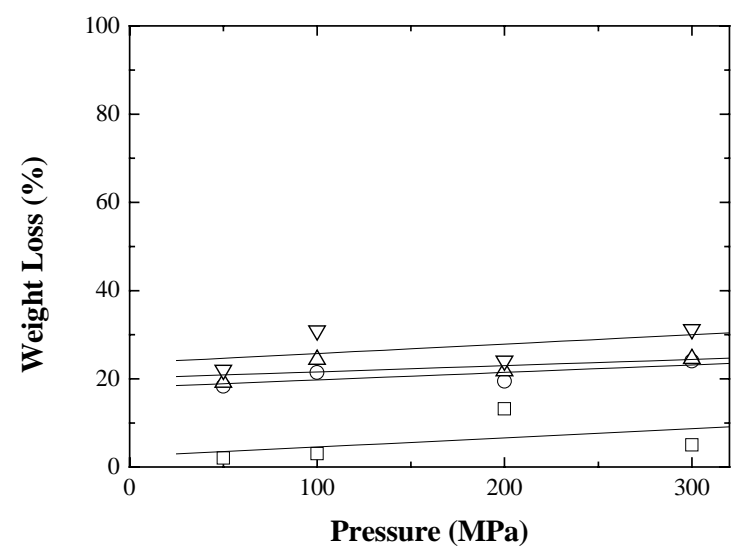

Fig. 2 Weight loss of the conjugated staple fibers by alkali hydrolysis as a function of the treating pressure at $60^{\circ} \mathrm{C}$ for $30 \mathrm{~min}$. The concentration of the surfactant: $0 \mathrm{~g} / \ell(\square), 0.5 \mathrm{~g} / \ell(\bigcirc), 1.0 \mathrm{~g} / \ell(\triangle)$, and $3.0 \mathrm{~g} / \ell(\nabla)$.
に残存していたポリエチレンテレフタレートを十分に取 り除いた後に,洗浄・乾燥してポリプロピレン繊維の重量 $R_{p}$ を測定した こここで重量減少率を次式により算出した．

$$
\text { Weight Loss }(\%)=\frac{\left(R_{t}-R_{p}\right)}{\left(R_{0}-R_{p}\right)}
$$

\section{4 活性化体積}

高圧下におけるアルカリ処理の変化量を推定するため， アルカリ加水分解反応を擬一次反応とし，次式より加水分 解の反応速度定数 $k$ を導いた。

$$
\ln \frac{\left(R_{t}-R_{p}\right)}{\left(R_{0}-R_{p}\right)}=-k t
$$

また，圧力による反応速度定数 $\mathrm{k}$ への効果を定量化す るため, van't Hoffにより式(2)のように定式化された反応 速度に対する静水圧効果の基礎理論を用い，活性化体積を 算出した。

$$
\Delta V^{\neq}=-\mathrm{R} T\left(\frac{\partial \ln k}{\partial P}\right) \mathrm{T}
$$

ここで, $\Delta V^{\neq}$は活性化体積， $\mathrm{R}$ は気体定数，Tは温度， $P$ は圧力を示す.遷移状態論において, 活性化体積は処理 の初期状態から反応による遷移状態に移行する際に生ず る体積変化のことである.アルカリ濃度や促進斉添加によ る活性化体積の増減を測定することで，各処理条件による 反応状態か推測できる.今回は, 活性化体積の処理温度お よび界面活性斉の添加量による变化について検討した .

\section{3. 結果と考察}

\section{1 高圧条件下でのアルカリ減量}

図 2 に，処理圧力を変化させて処理温度 $60^{\circ} \mathrm{C} て ゙ 30$ 分間 減量処理を行ったときの重量減少率の変化を示す.処理圧 力の増加にともなって重量減少率か増加した . また , 界面 活性剂を添加すると重量減量率が無添加時よりも20〜 30\%促進されたが,処理圧力か変化しても促進量は変化し

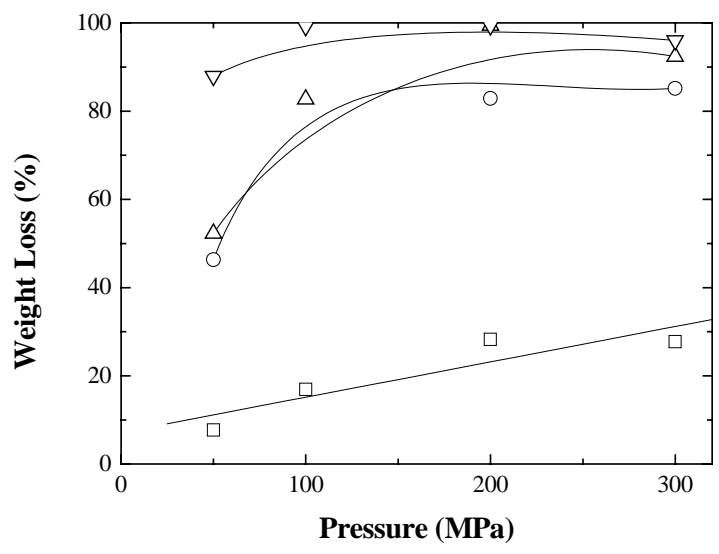

Fig. 3 Weight loss of the conjugated staple fiber by alkali hydrolysis as a function of the treating pressure at 100 ${ }^{\circ} \mathrm{C}$ for $30 \mathrm{~min}$. The concentration of the surfactant: $0 \mathrm{~g} / \ell(\square), 0.5 \mathrm{~g} / \ell(\bigcirc), 1.0 \mathrm{~g} / \ell(\triangle)$, and $3.0 \mathrm{~g} / \ell(\nabla)$. 


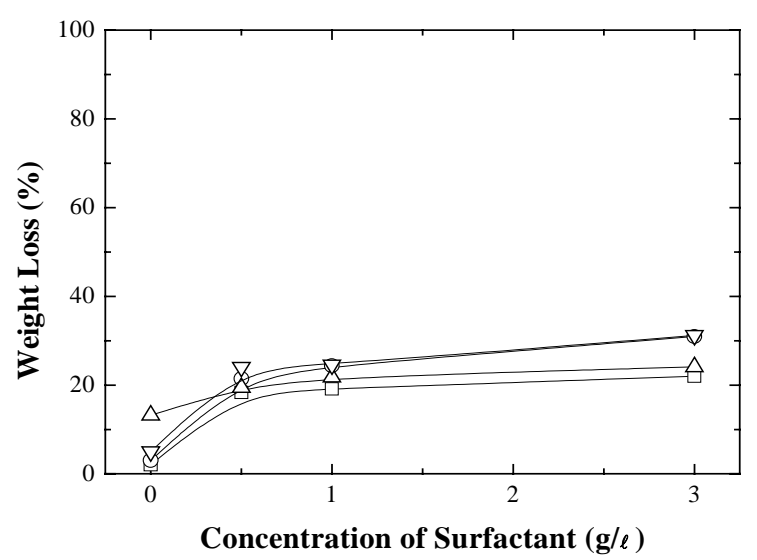

Fig. 4 Accelerating effect of the surfactant on the alkali hydrolysis of the conjugated fiber at $60{ }^{\circ} \mathrm{C}$ for $30 \mathrm{~min}$. Treating pressure: $50 \mathrm{MPa}(\square), 100 \mathrm{MPa}(\bigcirc), 200$ $\operatorname{MPa}(\triangle)$, and $300 \mathrm{MPa}(\nabla)$.

なかった . 图 3 には, 処理温度 $100{ }^{\circ} \mathrm{C}$ において同樣の実 験を行った結果をまとめた .界面活性阂を添加しない場合 には, $60{ }^{\circ} \mathrm{C}, 80{ }^{\circ} \mathrm{C}$ て処理したときより圧力による促進効 果が大きく現れた . また，界面活性阂の促進効果も $60^{\circ} \mathrm{C}$ のとき顕著に認められ，処理圧力 $100 \mathrm{MPa}$ 以上ではポリ エチレンテレフタレート成分がほぼ分解されるに至った . 処理温度 $60^{\circ} \mathrm{C}$ において 30 分間減量処理したときの， 界面活性剂による促進効果を图 4 に示す，添加した界面活 性剂の濃度が $1.0 \mathrm{~g} / \ell$ まででは, 添加濃度に伴い重量減少率 か増加したが, $1.0 \mathrm{~g} /$ 比上の高濃度に界面活性剂を添加し ても重量減少率の促進は飽和した $.80^{\circ} \mathrm{C}$ において処理し た場合においても，重量減少率は増加するものの促進効果 の飽和は同樣に $1.0 \mathrm{~g} / \ell$ 付近で生じた $.100{ }^{\circ} \mathrm{C}$ まで加熱して 減量処理を行うと, 界面活性斉添加による減量促進効果が 顕著となり，約 $1.0 \mathrm{~g} / \ell$ 界面活性剂を添加することで海成 分であるポリエチレンテレフタレートがほぼ分解された (図 5 ).

\section{2 高圧アルカリ減量反応の活性化体積}

図 6 には，高圧処理したときの重量減少率から式(2)を 用いて算出した反応速度定数 $k$ の処理圧力による変化を 示す. 界面活性剂の有無にかかわらず, アルカリ加水分解 反応の反応速度は処理圧力とともに増加した .

式(3)に従い，図6の傾きから活性化体積 $\Delta V^{\ddagger}$ を算出し， 产の処理温度による変化を图 7 に示す, 界面活性剂を無添 加の系では, $80^{\circ} \mathrm{C}$ において活性化体積か極小となるよう な傾向を示した .これは,ポリエチレンテレフタレートの ガラス転移温度が影響しているものと考えられる． $80{ }^{\circ} \mathrm{C}$ では纎維表面で起こっている加水分解反応が,ガラス転移 温度による僅かなミクロブラウン運動か阻害しているが， さらに温度を上げるとミクロブラウン運動が活発化し ,ア ルカリ剂が緎維内部に分散しやすくなり, 反応が起こる領 域を増加し, 弚れにともない活性化体積か増すものと推察 した。また，界面活性阂を添加すると，活性化体積が減少 したが,界面活性阂の添加量を変えても活性化体積はほぼ

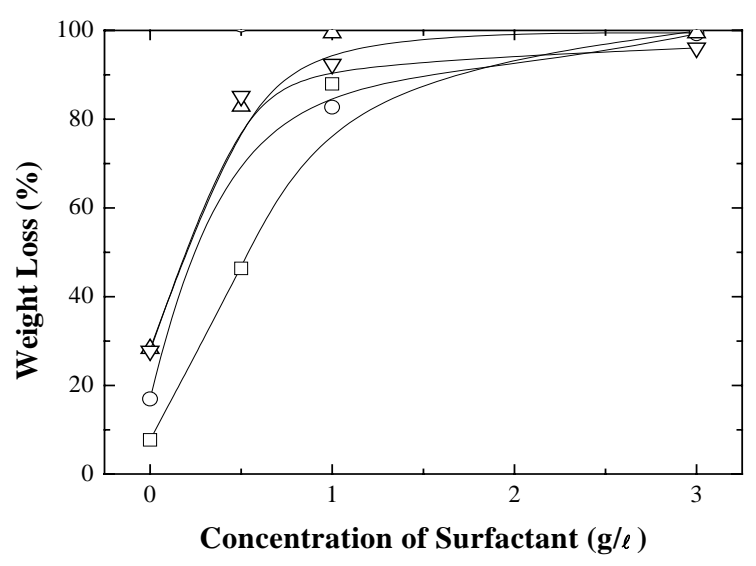

Fig. 5 Accelerating effect of the surfactant on the alkali hydrolysis of the conjugated fiber at $100{ }^{\circ} \mathrm{C}$ for $30 \mathrm{~min}$. Treating pressure: $50 \mathrm{MPa}(\square), 100 \mathrm{MPa}(\bigcirc), 200$ $\operatorname{MPa}(\triangle)$, and $300 \operatorname{MPa}(\nabla)$.

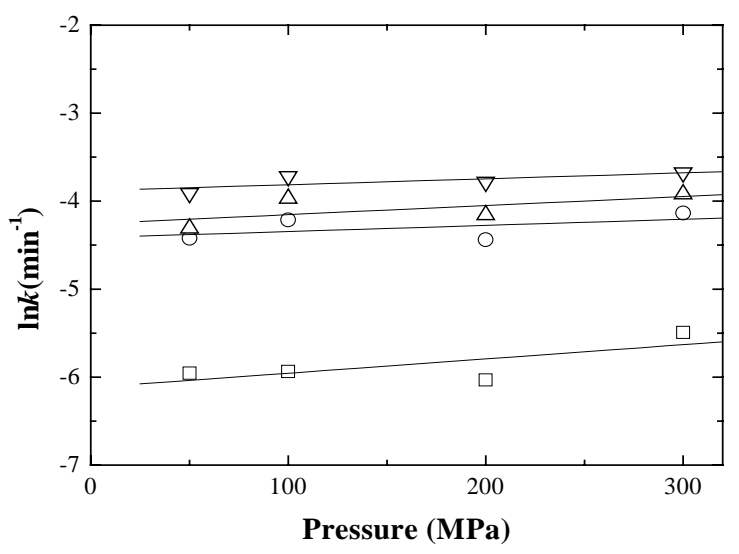

Fig. 6 Rate constants on the alkali hydrolysis as a function of pressure at $80{ }^{\circ} \mathrm{C}$. The concentration of the surfactant: $0 \mathrm{~g} / \ell(\square), 0.5 \mathrm{~g} / \ell(\bigcirc), 1.0 \mathrm{~g} / \ell(\triangle)$, and $3.0 \mathrm{~g} / \ell(\nabla)$.

同じであった (図 8 ).これは，ポリエステル織物を高圧 下でのアルカリ減量処理に対して, 界面活性斉添加したと きと活性化体積に及ぼす影響と同樣の傾向を示している ${ }^{2)}$. カチオン系界面活性剂は塩基性であることから, 加水分解 反応の触媒として作用することも考えられるが, 添加濃度 により促進効果がほとんど変化しなかったことから,直接 反応に関与しないかたちで重量減少率の向上に寄与して いると考えている.現在のところ，アルカリ加水分解によ り生じる疎水性の生成物が界面活性剂によって除去され る効果を有力視している 瀻維のアルカリ減量反応は不均 一反応であるため，纎維表面に生じた生成物を取り除き， 分解されるべきポリエチレンテレフタレートが常に露出 している状態となるために, 反応か俲率的に進行すると推 測している。

\section{3 電子顕微鏡写真}

図 9 には,アルカリ処理した短繊維の走査電子顕微鏡写 真 (1000 倍; a:重量減少率約 $55 \%$, b:重量減少率約 $95 \%)$ を示す.重量減少率 $55 \%$ では, 島部分のポリプロピレン 


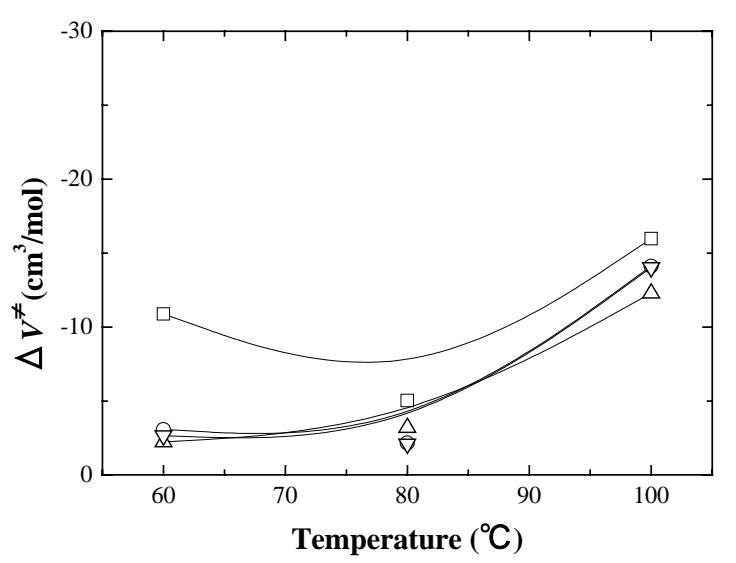

Fig. 7 Activation volume of the alkali hydrolysis as a function of temperature. The concentration of the surfactant: $0 \mathrm{~g} / \ell(\square), 0.5 \mathrm{~g} / \ell(\bigcirc), 1.0 \mathrm{~g} / \ell(\triangle)$, and $3.0 \mathrm{~g} / \ell(\nabla)$.

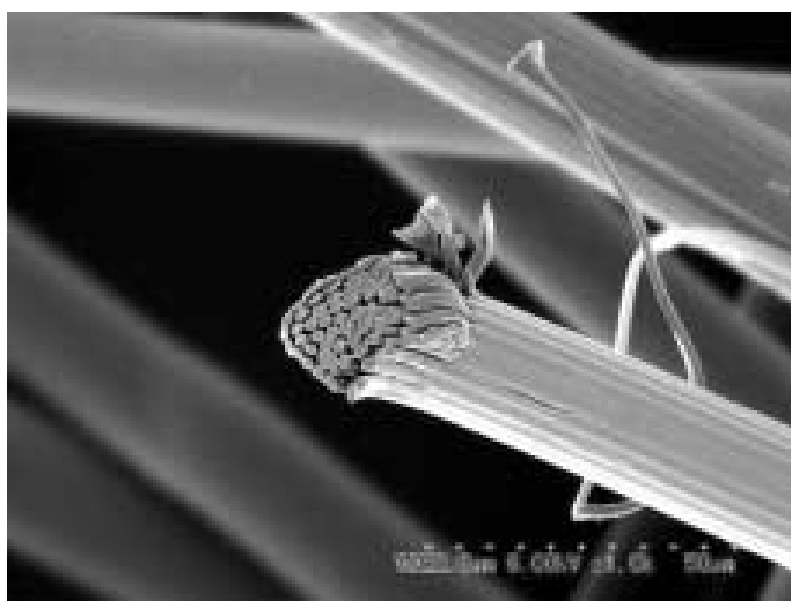

(a)

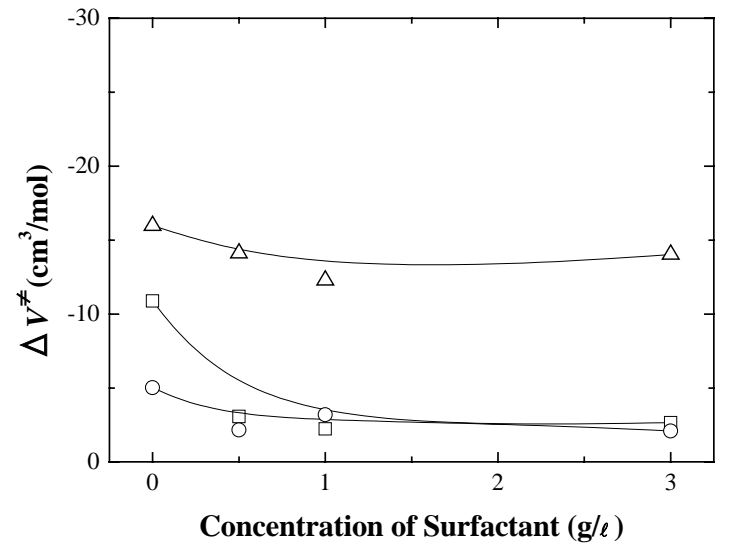

Fig. 8 Activation volume of the alkali hydrolysis as a function of the surfactant concentration. The reaction temperature: $60{ }^{\circ} \mathrm{C}(\square), 80{ }^{\circ} \mathrm{C}(\bigcirc)$ and $100{ }^{\circ} \mathrm{C}(\triangle)$.

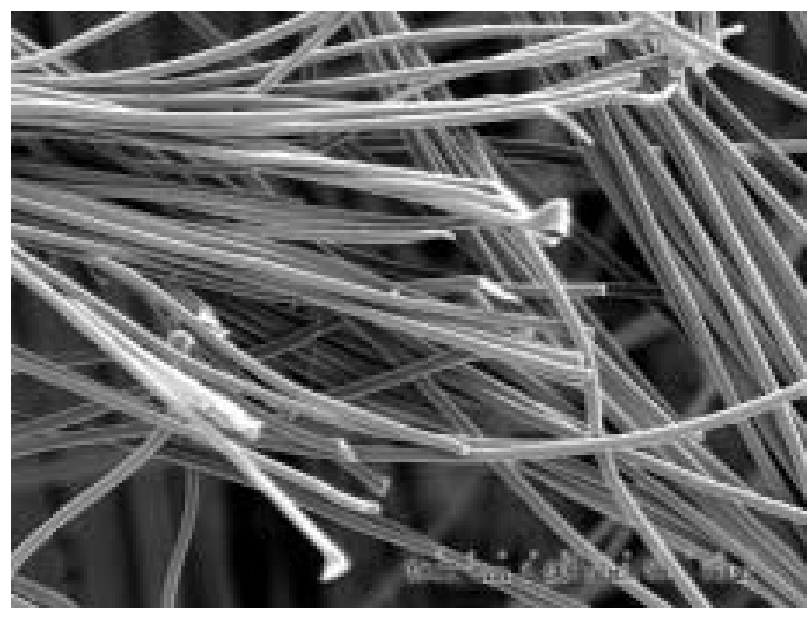

(b)

Fig. 9 SEM images for the conjugated staple fibers obtained after alkali hydrolysis $(\times 1000)$. Weight loss: (a) $55 \%$ and (b) $95 \%$.

繊維がはっきりと確認できるものの，残っているポリエチ レンテレフタレートが皮のようになり分割できずに束と なっていることがわかる.ポリプロピレンの分割はポリエ チレンテレフタレートの重量減少率 $30 \%$ 程度から一部分 割が始まり，重量減少率 $95 \%$ ではほとんど海成分である ポリエステルがなくなっているため,島部分のポリプロピ レンの極細短纎維がきれいに分割して広がっていること がわかった . (図9b)また, 分割の状態を温度, 圧力, 界面 活性剂の添加量等で比較したところ，光の分割状態はポリ エチレンテレフタレートの重量減少率に影響されていた .

\section{4. 結 言}

海島型 (ポリエチレンテレフタレート/ポリプロピレ ン) コンジュケート短繊維の分割方法について , 50MPa を越える高い圧力下でポリエチレンテレフタレートのア ルカリ加水分解処理による割繊方法を試み, 兴の圧力, 温 度およびアルカリ加水分解反応促進剂等による分解性へ
の影響について検討した．

谷の結果, 処理圧力, 処理温度の増加により重量減少率 が向上し,カチオン系界面活性剂の添加により重量減少率 が促進されることを確認した .また，処理圧力に伴う反応 速度定数の変化から導き出される活性化体積は, 界面活性 剂の添加により減少することを明らかにした．界面活性剂 の添加量によって, 促進効果が変化しなかったことから界 面活性斉は直接反応性を变化させるものではないが, 不均 一反応の反応場を活性化することにより反応を促進する ものと考えた .

\section{文 献}

1) 䋊維学会編, “最近の紡系技術”, 高分子刊行会, 京都, p.205 (1992).

2) Y. Shimbo, M. Kimizu, T. Abe, A. Tukuda, Sen'I Gakkai Preprints, G-121(1997).

3) M. Kimizu, Y. Shimbo, T. Hori, T. Abe, Fiber Preprints, Japan, P277(2000). 